\title{
Editorial:
}

\section{Rethinking social cohesion and its relationship to exclusion}

Since the March 2015 call for this special issue several key events have taken place in the country that belie the state's utopian vision of a supposed non-racial and socially cohesive South Africa. The growing sense of discord with this vision of cohesion has been evident in movements across the country such as Rhodes Must Fall, Open Stellenbosch Collective (OSC), Black Student Movement (Rhodes), and Fees Must Fall movement. 2015 also saw the upsurge of xenophobic violence across the country, anxieties over the country's economic future that translated into the recent and contentious Zuma Must Fall march. Service delivery protests across the country continue to highlight the sense of impatience for a better life. These events cannot be understood or discussed in isolation from the country's broader structural, socioeconomic and socio-history. Add to this the increasing 'race wars' currently being played out in the public domain of social media and increasing service delivery protests across the country. No doubt about it: South Africa remains racially and economically divisive in ways that make it impossible to imagine the possibilities for building "cohesion at the same time that we recognize, protect and give expression to difference" (Department of Arts and Culture, Social cohesion and social justice in SA, 2012 report, $p$ 13).

At the heart of this imagining of social cohesion in society are the often contested and ideological notions of what constitutes legitimate citizenship. Indeed, the exclusionary categories that inform the latter are continually shifting and being reinvented in ways that not only problematic the construct of cohesion, but also, challenge the state's project of national identity
Peace Kiguwa

University of the

Witwatersrand, Johannesburg

Peace.Kiguwa@wits.ac.za

Malose Langa

University of the

Witwatersrand, Johannesburg Malose.Langa@wits.ac.za 
constitution relative to everyday social practices and socio-histories of self-constitution. The social cohesion project must be interrogated, challenged and if found wanting, rejected. Indeed, the articles and reflections in this current issue draw attention to much state emphasis and concern with social cohesion objectives to the detriment of social justice. In drawing such a distinction, the authors recognize and highlight both the near impossibility as well as ideological function of social cohesion as aspiration and practice.

South Africa's transition to "violent democracy" (von Holdt, 2013: 590) remains marred by increasing violence (van der Merwe, 2014; Van Niekerk, Tonsing, Seedat, Jacobs, Ratele \& McClure, 2015). More recently, how do we understand resurgences of xenophobic violence without a concerted analytic engagement with both the violent history of the country as well as continued structural violence that the majority of South Africa's citizenry grapple with every day? A social justice concern and emphasis on poverty and the redistribution of material resources, for example, highlights the need to engage social cohesion objectives in more material ways that can genuinely begin to contribute to inclusivity in society. Until then, aspirations of an inclusive post-apartheid society remain almost impractical and at worst deliberately functional in sustaining inequalities. Indeed, it is a sense of injustice that underpins much local insurgent practice such as service delivery protests. As Mbembe (2015) observes “....what used to be taken for democracy and the political has been thoroughly hollowed out and redefined by finance, [...] levels of economic violence intensify to the point of triggering, in return, rising levels of political and social violence". Likewise, how do we read and understand gendered violence in society today in ways that do not merely reify particular gendered (raced and classed) bodies and identities as natural "victims" and "perpetrators" and yet still honor the embodied lived experiences of violence? Understanding and developing analytic tools that capture violence's complexity and its influence on social justice and cohesion objectives remain a challenging epistemological and methodological task for social scientists in South Africa today (Bowman, Stevens, Eagle, Langa, Kramer, Kiguwa \& Nduna, 2015).

Beginning to ponder on social justice and cohesion objectives in terms of inclusion means that we simultaneously engage questions of what inclusivity - and its related concept, exclusion - might mean. Lister (2000) chooses to engage inclusion and exclusion as inherently struggles between social cohesion and social justice - with the proviso that both these objectives are interdependent and not mutually exclusive. Social justice objectives further highlight the necessity for engaging sites of exclusion that include symbolic and identity struggles in contemporary South Africa. The project of decolonizing the university in South Africa today exemplifies such a process: recognizing that it is more than a struggle for material access and exclusion, characterized by the Fees Must Fall movement. Decolonization is also a re-visioning of symbolic and identity 
resources within higher education. What seems to have been less verbalized in the current struggles over access and symbolic representation is the important dialogue about curriculum transformation and what this process could look like. This process in the end must include discussion about how the university can and must remain a key site for epistemic disturbance (in the ways that challenge and disturb our theorization of the social world) and at the same time recognize and disrupt practices of epistemic violence (that are implicated in how certain bodies remain excluded and erased, both within material space and in the curriculum).

Social and subjective struggles currently taking place in the country require the attention of professionals within the discipline. Significantly, this must involve how we engage the discipline itself, interrogating our own complicities in sustaining the elite status of professional work in ways that reinforce and sustain inaccessibility as well as continues to render psychology apolitical in post-apartheid South Africa. Once again, the call for relevance (Macleod, 2004; Sher \& Long, 2012; Macleod \& Howell, 2013; Ratele, 2014; Kessi \& Kiguwa, 2015; Segalo, forthcoming) attests to an awareness of the discipline's inattention and yet potential for theorizing, researching, imagining and engaging the sociopolitical and academic citizenship. The struggle over belonging has also played out more generally within the public domain where public acts of racism have provided a platform for discussion on how race (and its intersections with class) are marked by a continuous process of denial and avoidance: this makes it possible to pinpoint particular individuals and collectives as embodying "by-gone" prejudices and racist ideology without engaging the racialized distribution of resources today and the continued economic and social violence enacted against a racial group.

We invited papers that engaged the nuances of social cohesion in post-apartheid South Africa today, grappling with critical reflections on what cohesion could mean in a society rife with social injustice. The papers and reflections engage different entry points to thinking about the complexities as well as the inherent problematic construct of social cohesion for our society. Ronelle Carolissen, Tamara Shefer and Estian Smit lead into this engagement by focusing on the disciplinary status and potential for contributing to a socially just curriculum. Focusing on practices of inclusion and exclusion within the curriculum and the discipline, the authors highlight the embodied, affective and discursive communities within which bodies as social texts both represent themselves and are represented by others.

The second paper by Yaseen Ally draws attention to moments of violence re/enactments within many marginalized communities and how these moments are considered legitimate by members of the community as a means of re-engaging social cohesion. Focusing on beliefs about witchcraft in a sample of community members, the paper 
argues that such mobilisation of fear of bewitchment dislocates important linkages and networks between people that make it impossible for socially cohesive communities.

Kopano Ratele's article engages more directly the disjuncture between social cohesion and social justice objectives, highlighting the impossibility and irrelevance of a social cohesion ideology that does not consider the necessity of socio-economic justice. The paper considers the potential of revising social cohesion discourse into socially-just solidarity in relation to the peculiarity of the black condition and engages the possibility of engaging sociohistorical condition as fundamental to such solidarity.

The four reflective papers further engage personally reflective grappling by the authors with the concept of social cohesion in different spheres. Ingrid Palmary takes up this issue with her overview of social cohesion discourse, its conflation with other concepts such as nationalism, and how it has been taken up in this particular moment. She interrogates the unproblematic deployment and embrace of this discourse without any real critical understanding of what such a concept truly offers South Africa today. Puleng Segalo's paper continues this interrogation of the unproblematic deployment of social cohesion as an ideal that ironically functions to enact violence on social groups. Focusing on the everyday as a core site of political oppression, the paper reflects on the mundanity and the everyday disciplinary domains of work and play as key sites of violent subjection. Using gender as a focal point of analysis, Segalo argues for critical reflection on the daily misrecognitions that particular gendered (raced and classed) bodies experience.

The third reflection paper by Gillian Eagle engages social cohesion as a difficult and often challenging notion to thinking about crime and community in South Africa today. In what ways can notions of social cohesion engage possibilities for community in the face of fear and violence? What potential and role of an active citizenry in engaging and building cohesion within communities? Are there tendencies toward fragmentation and/or possibly unification in the face of fear and crime? This reflection lays the groundwork for beginning to reflect on the function of liberal democracies in producing particular kinds of active citizenry through small-scale practices of community programs. Finally, Ashwin Desai closes off the discussion by reflecting on the increased significance the concept of social cohesion has come to take up in postapartheid South Africa. Desai provides a compelling argument for interrogating this salience in light of the widening socioeconomic gap in society. Even more so, such a concept downplays the actual fragmentary nature of this society and may in fact function to undermine growing tensions and resistances that challenge the status quo. Highlighting the necessity of redistribution as fundamental to any social cohesion project, the paper demonstrates that such a project must perhaps be superseded by economic social justice objectives. 
This special issue begins a conversation on social justice and psychology's role in participating in such a project today. We hope the contributors and readers of the issue continue to engage this important dialogue, foregrounding the as yet unrealized potential of the discipline to engage "relevance".

\section{References}

Bowman, B, Stevens, G, Eagle, G, Langa, M, Kramer, S, Kiguwa, P \& Nduna, M (2015) The second wave of violence scholarship: South African synergies with a global research agenda. Social Science \& Medicine, 146, 243-248.

Gray, J (2000) Inclusion: A radical critique?, in Askonas, P \& Stewart, A (eds) (2000) Social inclusion: Possibilities and tensions. Basingstoke: Macmillan.

Kessi, S \& Kiguwa, P (2015) Social psychology and social change: Beyond Western perspectives. Papers on Social Representations, 24, 1-11.

Lister, R (2000) Strategies for social inclusion: Promoting social cohesion or social justice?, in Askonas, P \& Stewart, A (eds) (2000) Social inclusion: Possibilities and tensions. Basingstoke: Macmillan.

Macleod, C (2004) South African psychology and 'relevance': Continuing challenges. South African Journal of Psychology, 34(4), 613-629.

Macleod, C \& Howell, S (2013) Reflecting on South African Psychology: Published research, 'relevance', and social issues. South African Journal of Psychology, 43(2), 222-237.

Mbembe, A (2015) The debt machine and the politics of $0 \%$. http://www.dailymaverick.co.za/article/2015-11-13-ground-up-op-ed-the-debtmachine-and-the-politics-of-0/

Ratele, K (2014) Psychology in society (PINS) and traditions: Back towards a critical African psychology. PINS (Psychology in society), 46, 50-59.

Segalo, P (forthcoming) Decolonizing Social Psychology in South Africa, in NdlovuGatsheni, S J \& Zondi, S (eds) (forthcoming) Decolonizing the university in Africa: Knowledge systems and disciplines. Durham, NC: Carolina Academic Press. 
Sher, D \& Long, W (2012) Historicising the relevance debate: South African and American psychology in context. South African Journal of Psychology, 42(4), 564-575.

Van der Merwe, $\mathrm{H}$ (2014) Violence as a form of communication: Making sense of violence in South Africa. African Journal on Conflict Resolution, 13(3), 65-84.

Van Niekerk, A, Tonsing, S, Seedat, M, Jacobs, R, Ratele, K \& McClure, R (2015) The invisibility of men in South African violence prevention policy: National prioritization, male vulnerability, and framing prevention. Global health action, 8: 27649 - http://dx.doi.org/10.3402/gha.v8.27649

Von Holdt, K (2013) South Africa: The transition to violent democracy. Review of African Political Economy, 40(138), 589-604. 